This document was prepared in conjunction with work accomplished under Contract No. DE-AC09-96SR18500 with the U. S. Department of Energy.

\title{
DISCLAIMER
}

This report was prepared as an account of work sponsored by an agency of the United States Government. Neither the United States Government nor any agency thereof, nor any of their employees, makes any warranty, express or implied, or assumes any legal liability or responsibility for the accuracy, completeness, or usefulness of any information, apparatus, product or process disclosed, or represents that its use would not infringe privately owned rights. Reference herein to any specific commercial product, process or service by trade name, trademark, manufacturer, or otherwise does not necessarily constitute or imply its endorsement, recommendation, or favoring by the United States Government or any agency thereof. The views and opinions of authors expressed herein do not necessarily state or reflect those of the United States Government or any agency thereof.

This report has been reproduced directly from the best available copy.

Available for sale to the public, in paper, from: U.S. Department of Commerce, National Technical Information Service, 5285 Port Royal Road, Springfield, VA 22161, phone: (800) 553-6847, fax: (703) 605-6900

email: orders@ntis.fedworld.gov

online ordering: http://www.ntis.gov/help/index.asp

Available electronically at http://www.osti.gov/bridge

Available for a processing fee to U.S. Department of Energy and its contractors, in paper, from: U.S. Department of Energy, Office of Scientific and Technical Information, P.O. Box 62, Oak Ridge, TN 37831-0062,

phone: (865)576-8401,

fax: (865)576-5728

email: $\underline{\text { reports@ adonis.osti.gov }}$ 
WSRC-TR-2003-00500, Rev. 0

\section{Uranium Metal Dissolution in the Presence of Fluoride and Boron}

KEYWORDS:

H-Canyon

Uranium

Metal

Dissolution

Nitric Acid

Fluoride

Robert A. Pierce

November 2003 
WSRC-TR-2003-00500, Rev. 0

Page 2 of 21

REVIEWS AND APPROVALS

Robert A. Pierce, Author, SRTC/SMTD/ATS

Michael G. Bronikowski, Technical Reviewer, SRTC/SMTD/ATS

William H. Clifton, Jr., Technical Review, Technical Engineering

Alice M. Murray, Group Manager, SRTC/SMTD/ATS
Date:

\section{Date}

Date

Date 


\section{SUMMARY}

$\mathrm{H}$-Area Operations is planning to process plutonium-contaminated (Pu-contaminated) uranium metal scrap in its efforts to de-inventory excess nuclear materials. The use of $\mathrm{H}-$ Canyon and HB-Line was evaluated for feasibility in meeting processing targets and requirements. SRTC performed flowsheet development to support the decision about how and where the scrap will be processed. Specifically, experimental work was performed to (1) gather reaction rate data at a range of processing conditions, (2) generate data for calculating hydrogen and total gas generation rates, (3) propose a process flowsheet, and (4) demonstrate that the proposed flowsheet does not pose a criticality hazard.

Uranium metal dissolution experiments have shown that acceptable dissolution rates can be achieved for the $\mathrm{Pu}$-contaminated scrap program using either nitric acid $\left(\mathrm{HNO}_{3}\right)$ concentrations above $7 \mathrm{M}$ or low $\mathrm{HNO}_{3}$ concentrations (1-4M) in the presence of fluoride and boron. At low acid concentrations in the absence of fluoride, the reaction rates are unacceptably slow for the Pu-contaminated scrap program. The observed behavior of dissolution rates as a function of acid concentration and temperature are in general agreement with what is expected based on the literature.

Gas generation tests have demonstrated that hydrogen generation is not an issue at the conditions being proposed for plant operations. At $\mathrm{HNO}_{3}$ concentrations above $2 \mathrm{M}$, the hydrogen component of the offgas is less that $0.1 \%$ by volume. The total amount of gas generation will be approximately $18.6 \mathrm{~mL} / \mathrm{hr}$ per square centimeter of exposed metal surface area.

Mixing studies have shown that criticality is not a likely event in the dissolver insert either at room temperature or at $100^{\circ} \mathrm{C}$. In $2 \mathrm{M} \mathrm{HNO}_{3} / 0.025 \mathrm{M}$ potassium fluoride $(\mathrm{KF})$ and $2 \mathrm{~g} / \mathrm{L}$ boron (B) at room temperature, a steady gas stream is generated from the surface of uranium metal. The gas generation rate is sufficient to mix the contents of the dissolver insert. In $4 \mathrm{M} \mathrm{HNO}_{3} / 0.025 \mathrm{M} \mathrm{KF}$ and $2 \mathrm{~g} / \mathrm{L}$ boron, there is insufficient gas generation to disperse the dissolved uranium. Instead of mixing, the denser uranium solution drops down out of the dissolver insert and away from the metal being dissolved. Variations in acid concentration away from $2 \mathrm{M} \mathrm{HNO}_{3}$ should not be a problem since dissolution in both $1 \mathrm{M}$ or $3 \mathrm{M} \mathrm{HNO}_{3}$ (with $\mathrm{KF}$ and boron) at room temperature produces gas generation comparable to that of $2 \mathrm{M} \mathrm{HNO}_{3}$. When the temperature is raised to $100^{\circ} \mathrm{C}$, the gas generation at $1-4 \mathrm{M} \mathrm{HNO}_{3}$ in $0.025 \mathrm{M} \mathrm{KF}$ and $2 \mathrm{~g} / \mathrm{L}$ boron exceeds that of $2 \mathrm{M} \mathrm{HNO}_{3}$ at room temperature, and thus will provide excellent mixing in the dissolver insert.

Based on reactions at room temperature and boiling, and the rates of reaction at $100^{\circ} \mathrm{C}$, SRTC recommends the use of $2 \mathrm{M} \mathrm{HNO}_{3} / 0.025 \mathrm{M} \mathrm{KF}$ and $2 \mathrm{~g} / \mathrm{L}$ boron at boiling in $\mathrm{H}-$ Canyon to process the $\mathrm{Pu}$-contaminated scrap material. 


\section{INTRODUCTION}

$\mathrm{H}$-Area Operations is planning to process plutonium-contaminated (Pu-contaminated) uranium metal scrap in its efforts to de-inventory excess nuclear materials. The use of $\mathrm{H}$ Canyon and HB-Line was evaluated for feasibility in meeting processing targets and requirements. The Actinide Technology Section of the Savannah River Technology Center (SRTC) performed flowsheet development to support the decision about how and where the scrap will be processed.

Experimental work was performed with a piece of uranium sheet. The study had four primary objectives. First, gather reaction rate data at a range of processing conditions to compare against reaction rate data reported in earlier studies and recommend a flowsheet for H-Canyon and/or for HB-Line. Second, develop new data for calculating hydrogen and total generation rates during uranium metal dissolution. Third, the tests intend to provide data to help demonstrate that the proposed flowsheet does not pose a criticality hazard. Last, use the data to recommend a process flowsheet.

\section{EXPERIMENTAL}

The experimental program for the Pu-contaminated scrap campaign involved three basic types of experiments. The first type was the collection of general dissolution rate data as a function of temperature and solution concentrations. The second type of test was for gas generation designed to measure offgas volume and concentration as a function of solution concentrations. The third set determined if sufficient mixing occurs during dissolution to prevent the creation of conditions that could lead to a criticality event. All tests were performed with small pieces of enriched uranium metal all cut from a larger sheet of metal. The sheet has a uniform thickness.

\section{Dissolution Rate Measurements}

Initial reaction rates were measured at six process conditions: $2 \mathrm{M}$ nitric acid $\left(\mathrm{HNO}_{3}\right), 4 \mathrm{M}$ $\mathrm{HNO}_{3}, 7 \mathrm{M} \mathrm{HNO}_{3}, 10 \mathrm{M} \mathrm{HNO}_{3}, 2 \mathrm{M} \mathrm{HNO}_{3} / 2 \mathrm{M} \mathrm{NaNO}_{3}$, and $4 \mathrm{M} \mathrm{HNO}_{3} / 3 \mathrm{M}$ sodium nitrate $\left(\mathrm{NaNO}_{3}\right)$. Subsequent studies evaluated reaction rates for $2 \mathrm{M} \mathrm{HNO}_{3}$ and $4 \mathrm{M} \mathrm{HNO}_{3}$ in the presence of $2 \mathrm{~g} / \mathrm{L}$ boron and 0.01-0.1M potassium fluoride (KF). Several temperatures were studied for most of the solutions.

Dissolution rates were measured as follows. A small piece of uranium metal plate was

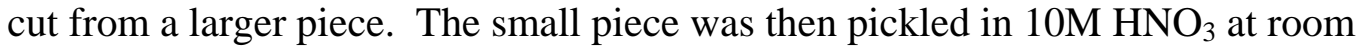
temperature for 3-4 minutes to remove the oxide coating; initial pickling typically removed about $5 \%$ of the weight as oxide. The physical dimensions (width, length, thickness, mass) of the sample were then measured. A balance was used to measure weight; calipers were used to measure width, length, and thickness. It is important to note that the balance in the glovebox measures only to 0.001 grams. Therefore, the uncertainty on small weight changes can be quite large. 
Next, a beaker was filled with a known amount of dissolver solution and placed on a hot plate/stirrer. The beaker also contained a sample holder to allow solution access to both sides of the sample without interfering with the stirring (see Figure 1). The solution was heated to a set temperature while the contents were stirred. When at temperature, a pickled sample was placed in solution for a measured amount of time. At the end of the test, the metal sample was removed, rinsed with water, dried, and weighed. Reaction rate was determined as weight loss per unit surface area per unit time.

\section{Gas Generation Tests}

Tests were performed to measure both the generation rates and composition of gases generated during the dissolution of uranium metal at different acid concentrations. Of particular interest is the amount of hydrogen gas

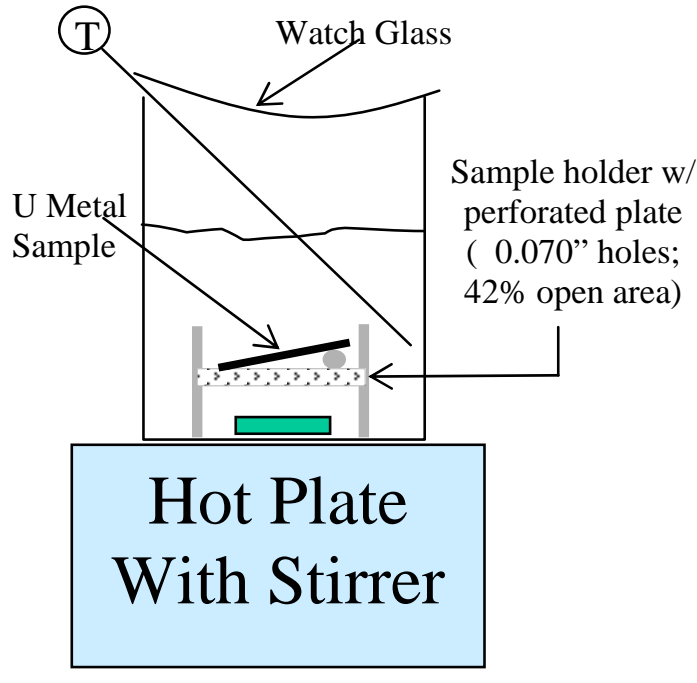

Figure 1. Reaction Rate Setup generated per mass of metal dissolved. Conditions tested include $10 \mathrm{M} \mathrm{HNO}_{3}, 7 \mathrm{M} \mathrm{HNO}_{3}$ and $4 \mathrm{M} \mathrm{HNO}_{3}$ without boron or fluoride; in presence of $2 \mathrm{~g} / \mathrm{L}$ boron and $0.025 \mathrm{M} \mathrm{KF}, 4 \mathrm{M}$ $\mathrm{HNO}_{3}, 2 \mathrm{M} \mathrm{HNO}_{3}$, and $1 \mathrm{M} \mathrm{HNO}_{3}$ solutions were tested.

A system was set up as shown in Figure 2. The system was a sealed glass vessel designed to prevent the introduction or loss of gas. The vessel was filled with $350 \mathrm{~mL}$ of liquid to fill the majority of the $400 \mathrm{~mL}$ of space in the system. The liquid was heated to $100^{\circ} \mathrm{C}$, the dissolution temperature selected for these tests. Once at temperature, the head space and lines of the system were purged with an inert gas. For $10 \mathrm{M} \mathrm{HNO}_{3}$ and $7 \mathrm{M} \mathrm{HNO}_{3}$, nitrogen was used to purge the system; $\mathrm{CO}_{2}$ was used for the other four test conditions to avoid interference with nitrogen analyses when dissolving at lower acid concentrations.

After the system had been purged, a pickled and weighed uranium metal sample was added to the vessel, and the vessel was sealed. The sample sits on the bottom of the vessel. As gases are generated, they were collected in a gas-sample bag fitted

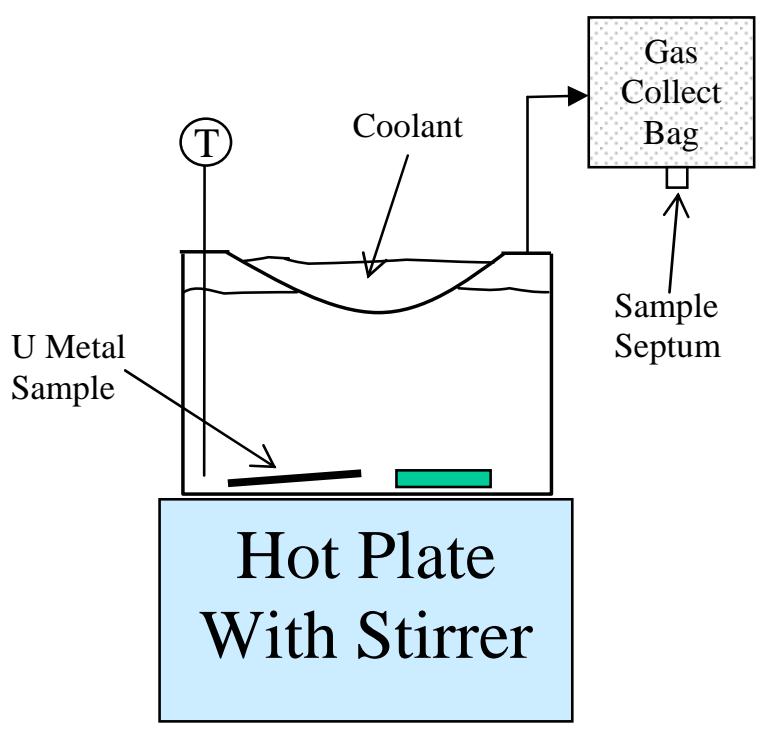

Figure 2. Gas Generation Setup with a valve and sample septum. After the metal sample had dissolved and gas generation had ceased, $20 \mathrm{~mL}$ of gas sample was collected in a syringe and the residual gas volume was measured using displacement of water. 
It should be noted that the first gas generation test $\left(10 \mathrm{M} \mathrm{HNO}_{3}\right)$ was performed with an inverted burette to capture the gas and measure its volume. However, it was found that the water in the burette was absorbing the nitrogen dioxide $\left(\mathrm{NO}_{2}\right)$ from the gas phase faster than anticipated. As a result, the gas volume could not be measured. Nonetheless, a gas sample could still be obtained from the dissolution vessel. Also, the gas generation test at $1 \mathrm{M} \mathrm{HNO}_{3} / 0.025 \mathrm{M} \mathrm{KF}$ and $2 \mathrm{~g} / \mathrm{L}$ boron was initiated at room temperature to observe the room temperature gas generation and mixing in support of the mixing studies discussed below.

\section{Mixing Studies}

Another system was set up to observe the mixing that occurs during dissolution of uranium metal in a simulated dissolver insert at room temperature. No external mixing was provided so that system mixing was solely a function of gas generation due to reaction. The tests aim to determine whether dissolved uranium concentrated in a stagnant layer around the piece that was dissolving, hence creating a criticality concern.

A picture of the system used for the mixing studies is provided in Figure 3. The outer tube (LEFT) represents the dissolver that will contain the bulk dissolver solution. The simulated dissolver dissolver insert is shown CENTER and RIGHT. The simulated dissolver insert contains a perforated plate up from the bottom of the dissolver insert, similar to the actual dissolver insert, to allow liquid to access the sample from above and
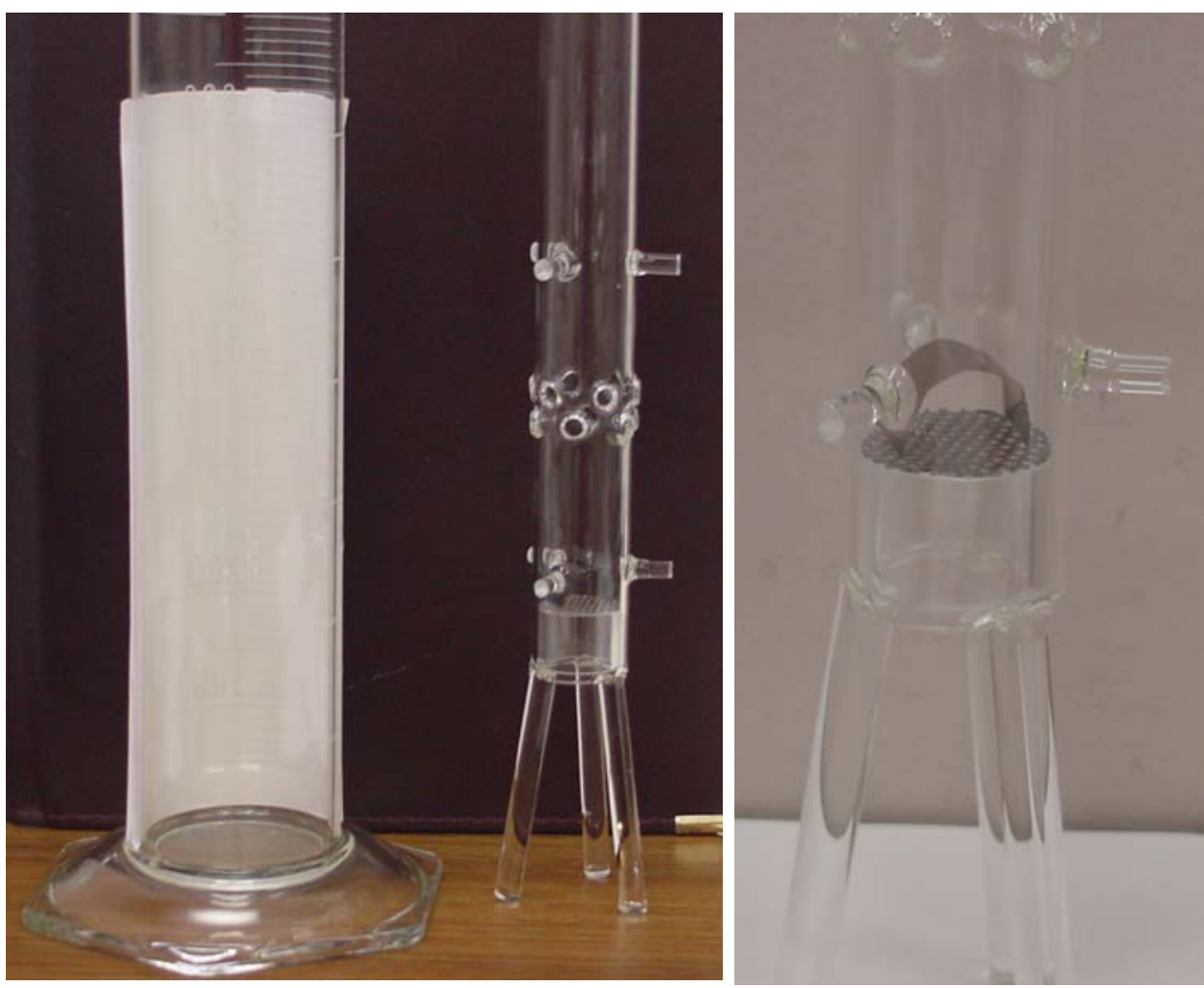

Figure 3. Mixing Test Assembly 
below. The sample will sit on the perforated plate as a half circle (RIGHT). The simulated tube also contain holes above the sample to allow solution to flow between the dissolver insert and bulk solution in a manner comparable to the actual dissolver insert.

Three tests were performed in the mixing test assembly $-2 \mathrm{M} \mathrm{HNO}_{3}, 3 \mathrm{M} \mathrm{HNO}_{3}$, and $4 \mathrm{M}$ $\mathrm{HNO}_{3}$, all in the presence of $2 \mathrm{~g} / \mathrm{L}$ boron and $0.025 \mathrm{M} \mathrm{KF}$. The system was charged with a pickled, weighed sample of uranium metal. The piece was bent to form a $180^{\circ}$ arc similar to Figure 3. Next, $500 \mathrm{~mL}$ of liquid was added to the system so that the liquid level was above the level of the holes. Observations were then made of gas generation and uranium partitioning in the system as a function of time. Pictures and videos of the tests were taken for additional studies of the test results.

The first test was performed with $4 \mathrm{M} \mathrm{HNO}_{3}$ and ran for 22 hours. The second test was run in $2 \mathrm{M} \mathrm{HNO}_{3}$ and operated for 5.5 hours. After 3.5 hours in the $2 \mathrm{M} \mathrm{HNO}_{3}$ test, a second metal sample was introduced to develop a better understanding of the reaction and mixing characteristics. The test with $3 \mathrm{M} \mathrm{HNO}_{3}$ was an abbreviated test (3.25 hours) that was aimed at only observing the gas generation characteristics for comparison with the first two tests. The $3 \mathrm{M} \mathrm{HNO}_{3}$ solution was prepared from 50:50 mixture of used $2 \mathrm{M}$ and $4 \mathrm{M} \mathrm{HNO}_{3}$ solutions used in the first two tests. In addition to the results obtained from the above mixing studies, other observations of mixing during other studies were obtained, as appropriate.

\section{RESULTS}

\section{Dissolution Rate Measurements}

The first set of tests focused on using only $\mathrm{HNO}_{3}$ at $100-105^{\circ} \mathrm{C}$. The data are contained in Table 1. A general increase of dissolution rate with increasing acid concentration is observed. Also, the two data sets at $4 \mathrm{M}$ total nitrate and the two sets at $7 \mathrm{M}$ total nitrate show good agreement even though the acidity varies within the data sets.

Table 1. Measured Dissolution Rates in Nitric Acid

\begin{tabular}{|c|c|c|c|c|c|}
\hline \multicolumn{6}{|c|}{ Rate $\left(\mathrm{mg} / \mathrm{min}-\mathrm{cm}^{2}\right)$ at Temperature $\left({ }^{\circ} \mathrm{C}\right)$} \\
\hline Solution & $20-25^{\circ} \mathrm{C}$ & $50^{\circ} \mathrm{C}$ & $60^{\circ} \mathrm{C}$ & $80^{\circ} \mathrm{C}$ & $100^{\circ} \mathrm{C}$ \\
\hline $2 \mathrm{M} \mathrm{HNO}_{3}$ & --- & --- & $\mathrm{nd}^{*}$ & 0.007 & 0.051 \\
\hline \multicolumn{6}{|c|}{ nd $=$ not detected } \\
\hline \multicolumn{6}{|c|}{ Rate $\left(\mathrm{mg} / \mathrm{min}-\mathrm{cm}^{2}\right)$ at Temperature $\left({ }^{\circ} \mathrm{C}\right)$} \\
\hline Solution & $20-25^{\circ} \mathrm{C}$ & $50^{\circ} \mathrm{C}$ & $65^{\circ} \mathrm{C}$ & $85^{\circ} \mathrm{C}$ & $105^{\circ} \mathrm{C}$ \\
\hline $2 \mathrm{M} \mathrm{HNO}_{3} / 2 \mathrm{M} \mathrm{NaNO}_{3}$ & --- & --- & --- & --- & 0.254 \\
\hline $4 \mathrm{M} \mathrm{HNO}_{3}$ & --- & --- & 0.003 & 0.041 & 0.309 \\
\hline $4 \mathrm{M} \mathrm{HNO}_{3} / 3 \mathrm{M} \mathrm{NaNO}{ }_{3}$ & --- & --- & --- & --- & 1.258 \\
\hline $7 \mathrm{M} \mathrm{HNO}_{3}$ & 0.005 & --- & 0.074 & 0.841 & 1.285 \\
\hline $10 \mathrm{M} \mathrm{HNO}_{3}$ & --- & --- & 1.637 & 3.496 & 4.057 \\
\hline
\end{tabular}

During the tests with $2 \mathrm{M}$ and $4 \mathrm{M} \mathrm{HNO}_{3}$, it was observed that the gas generation would start and stop throughout the test. Closer inspection of the samples indicated that the samples had a dull surface to them. Because it was speculated that there was an oxide 
coating on the samples even in the acid, additional experiments were performed with varying amounts of $\mathrm{KF}$ and boron ( $2 \mathrm{~g} / \mathrm{L}$ boron added as boric acid). Although there is an initial oxide coating on the sample from exposure to air, empirical data suggests that a coating persists (or reforms) in solution at low KF concentration.

The data are listed in Table 2 to show the effect of varying KF concentrations. Except where stated, all solutions in Table 2 included boron. After boron was added, an increased shine on the surface of the samples was observed with increasing $\mathrm{KF}$ concentration. This shine was observed when the samples were being weighed after dissolution. A sample dissolved in $2 \mathrm{M}$ $\mathrm{HNO}_{3} / 0.1 \mathrm{M} \mathrm{KF}$ is shown in Figure 4.

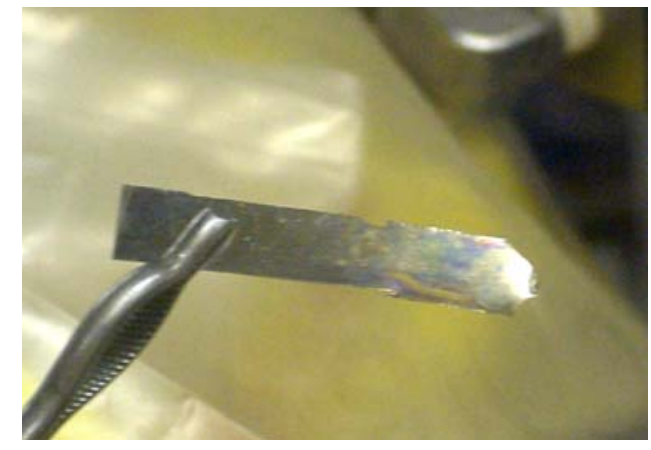

Figure 4. Stripped Uranium Metal

Table 2. Measured Dissolution Rates in Nitric Acid with Fluoride and Boron

\begin{tabular}{|c|c|c|c|c|c|}
\hline \multicolumn{6}{|c|}{ Rate $\left(\mathrm{mg} / \mathrm{min}-\mathrm{cm}^{2}\right)$ at Temperature $\left({ }^{\circ} \mathrm{C}\right)$} \\
\hline Solution & $20-25^{\circ} \mathrm{C}$ & $50^{\circ} \mathrm{C}$ & $60^{\circ} \mathrm{C}$ & $80^{\circ} \mathrm{C}$ & $100^{\circ} \mathrm{C}$ \\
\hline $2 \mathrm{M} \mathrm{HNO}_{3}$ (no boron) & --- & --- & $\mathrm{nd}^{*}$ & 0.007 & 0.051 \\
\hline $2 \mathrm{M} \mathrm{HNO}_{3} / 0.01 \mathrm{M} \mathrm{KF}$ & 0.099 & 0.308 & --- & --- & 1.066 \\
\hline $2 \mathrm{M} \mathrm{HNO}_{3} / 0.025 \mathrm{M} \mathrm{KF}$ & 0.137 & 0.54 & --- & --- & 2.348 \\
\hline $2 \mathrm{M} \mathrm{HNO}_{3} / 0.05 \mathrm{M} \mathrm{KF}$ & --- & --- & --- & --- & 6.480 \\
\hline $2 \mathrm{M} \mathrm{HNO}_{3} / 0.1 \mathrm{M} \mathrm{KF}$ & --- & --- & --- & --- & 12.574 \\
\hline $\begin{array}{l}2 \mathrm{M} \mathrm{HNO}_{3} / 0.1 \mathrm{M} \mathrm{KF} \\
\text { (no boron) }\end{array}$ & 0.213 & --- & --- & --- & 18.491 \\
\hline \multicolumn{6}{|c|}{$n d=$ not detected } \\
\hline \multicolumn{6}{|c|}{ Rate $\left(\mathrm{mg} / \mathrm{min}-\mathrm{cm}^{2}\right)$ at Temperature $\left({ }^{\circ} \mathrm{C}\right)$} \\
\hline Solution & $20-25^{\circ} \mathrm{C}$ & $50^{\circ} \mathrm{C}$ & $65^{\circ} \mathrm{C}$ & $85^{\circ} \mathrm{C}$ & $105^{\circ} \mathrm{C}$ \\
\hline $4 \mathrm{M} \mathrm{HNO}_{3}$ (no boron) & --- & --- & 0.003 & 0.041 & 0.309 \\
\hline $4 \mathrm{M} \mathrm{HNO}_{3} / 0.01 \mathrm{M} \mathrm{KF}$ & 0.097 & 0.293 & --- & --- & 1.307 \\
\hline $4 \mathrm{M} \mathrm{HNO}_{3} / 0.025 \mathrm{M} \mathrm{KF}$ & 0.097 & 0.37 & --- & --- & 3.163 \\
\hline $4 \mathrm{M} \mathrm{HNO}_{3} / 0.05 \mathrm{M} \mathrm{KF}$ & --- & --- & --- & --- & 6.485 \\
\hline $4 \mathrm{M} \mathrm{HNO}_{3} / 0.1 \mathrm{M} \mathrm{KF}$ & 0.541 & --- & --- & --- & 20.464 \\
\hline
\end{tabular}

For one test in $2 \mathrm{M} \mathrm{HNO}_{3} / 0.025 \mathrm{M} \mathrm{KF}$ and $2 \mathrm{~g} / \mathrm{L}$ boron, the sample was dissolved at room temperature without being pickled prior to coming in contact with the acid. No stirring was provided. The dissolution rate at room temperature was $0.323 \mathrm{mg} / \mathrm{min}$-sq.cm over 20 minutes. When compared to the pickled rate of about $0.137 \mathrm{mg} / \mathrm{min}-\mathrm{sq} . \mathrm{cm}$, the data indicates that the oxide coating dissolves faster than the base metal. Also, after the 20 minutes of dissolution, the sample no longer had a visible oxide coating; it had a dull silver color instead of charcoal gray.

\section{Gas Generation Tests}

The rate of dissolution for each of the gas generation tests reflected what was observed in the dissolution rate measurement experiments. The gas volume measurements are made with the gas at ambient temperature and pressure. In each case, a significant amount of 
orange fumes was observed in the gas sample bag, indicating the presence of $\mathrm{NO}_{2}$. The raw data are listed in Table 3. Based on the presence of oxygen, it appears as though some air has leaked into the $7 \mathrm{M} \mathrm{HNO}_{3}$ sample and may have affected the $\mathrm{NO}: \mathrm{NO}_{2}$ ratio. All data listed as " $<0.1 \%$ " in Tables 3 and 4 are below the detection limit.

When the data are normalized to omit the presence of the purge gas and list the "Undefined" as $\mathrm{NO}_{2}$, the data in Table 4 are obtained. As will be discussed later, there is reason to expect that some of the "Undefined" gas of $1 \mathrm{M} \mathrm{HNO}_{3} / 0.025 \mathrm{M} \mathrm{KF}$ also contains a significant fraction of $\mathrm{N}_{2} \mathrm{O}$. The total gas generated (in $\mathrm{mL} / \mathrm{g} \mathrm{U}$ ) is not affected by the presence of the purge gas because the total displacement of gas into the sample bag is solely a function of the amount of gas generated by the reaction.

Table 3. Gas Generation Data

\begin{tabular}{|c|c|c|c|c|c|c|c|}
\hline Solution & $\begin{array}{c}\text { Gas } \\
(\mathrm{mL} / \mathrm{g} \mathrm{U})\end{array}$ & $\mathrm{H}_{2}(\%)$ & $\mathrm{N}_{2}(\%)$ & $\mathrm{O}_{2}(\%)$ & $\mathrm{CO}_{2}(\%)$ & NO (\%) & Undef (\%)* \\
\hline $\begin{array}{l}1 \mathrm{M} \mathrm{HNO}_{3} / 0.025 \mathrm{M} \mathrm{KF} \\
\text { and } 2 \mathrm{~g} / \mathrm{L} \text { boron }\end{array}$ & 131 & 4.4 & $<0.1$ & $<0.1$ & 18 & 3.2 & 74 \\
\hline $\begin{array}{l}2 \mathrm{M} \mathrm{HNO}_{3} / 0.025 \mathrm{M} \mathrm{KF} \\
\text { and } 2 \mathrm{~g} / \mathrm{L} \text { boron }\end{array}$ & 64 & 0.07 & $<0.1$ & $<0.1$ & 13 & 77 & 10 \\
\hline $\begin{array}{l}4 \mathrm{M} \mathrm{HNO}_{3} / 0.025 \mathrm{M} \mathrm{KF} \\
\text { and } 2 \mathrm{~g} / \mathrm{L} \text { boron }\end{array}$ & 132 & $<0.1$ & $<0.1$ & $<0.1$ & 2.1 & 83 & 15 \\
\hline $4 \mathrm{M} \mathrm{HNO}_{3}$ & 103 & $<0.1$ & $<0.1$ & $<0.1$ & 30 & 32 & 38 \\
\hline $7 \mathrm{M} \mathrm{HNO}_{3}$ & 111 & $<0.1$ & 80 & 4.1 & $<0.1$ & 0.7 & 15 \\
\hline $10 \mathrm{M} \mathrm{HNO} 3$ & $\mathrm{n} / \mathrm{a}$ & $<0.1$ & 71 & $<0.1$ & $<0.1$ & 8.1 & 21 \\
\hline
\end{tabular}

* Undefined component is likely $\mathrm{NO}_{2}$ and/or $\mathrm{N}_{2} \mathrm{O}$

Table 4. Normalized Gas Generation Data

\begin{tabular}{|l|c|c|c|c|c|}
\hline Solution & $\begin{array}{c}\text { Gas } \\
\text { (mL/g U) }\end{array}$ & H2 (\%) & O2 (\%) & NO (\%) & NO2 (\%) \\
\hline 1M HNO3/0.025M KF & 131 & 5.4 & $<0.1$ & 3.9 & $90.7^{*}$ \\
2M HNO3/0.025M KF & 64 & 0.08 & $<0.1$ & 88.5 & 11.5 \\
4M HNO3/0.025M KF & 132 & $<0.1$ & $<0.1$ & 84.8 & 15.2 \\
$4 \mathrm{M}$ HNO3 & 103 & $<0.1$ & $<0.1$ & 45.7 & 54.3 \\
7M HNO3 & 111 & $<0.1$ & $<0.1$ & 4.4 & 95.6 \\
10M HNO3 & n/a & $<0.1$ & $<0.1$ & 27.9 & 72.1 \\
\hline
\end{tabular}

* May contain high fraction of $\mathrm{N}_{2} \mathrm{O}$

\section{Mixing Studies}

The two primary mixing studies at room temperature $\left(2 \mathrm{M}\right.$ and $4 \mathrm{M} \mathrm{HNO}_{3}$ with $\mathrm{KF}$ and boron) yielded very different results, particularly in comparison with their behavior at $100^{\circ} \mathrm{C}$ (in gas generation and dissolution rate tests). At $100^{\circ} \mathrm{C}$, both conditions create an abundance of gas that creates mixing within the vessel. A picture of metal dissolution in $4 \mathrm{M} \mathrm{HNO}_{3} / 0.025 \mathrm{M} \mathrm{KF}$ and $2 \mathrm{~g} / \mathrm{L}$ boron is shown as Figure 5.

When the mixing study was performed with $2 \mathrm{M} \mathrm{HNO}_{3} / 0.025 \mathrm{M} \mathrm{KF}$ and $2 \mathrm{~g} / \mathrm{L}$ boron at $25^{\circ} \mathrm{C}$, the behavior was consistent with what is observed at $100^{\circ} \mathrm{C}$ except that the gas 
generation rate is slower. After the sample comes in contact with the acid, it is only a few minutes before very tiny gas bubbles begin to effervesce from the metal surface. Because of the presence of fluoride, the uranium first forms a relatively stable blue U(IV) complex. ${ }^{1}$ Over time in $\mathrm{HNO}_{3}$, or in the presence of heat, the $\mathrm{U}(\mathrm{IV})$ is converted to the distinctive yellow U(VI) form as seen in Figure 5.

The generation of gas disperses the dissolving uranium throughout the insert and outer vessel. After about 90 minutes, the gas generation begins to stop and start. On a few occasions, the vessel was bumped and almost immediately the gas generation was renewed. Late into the test, a second piece of uranium was added. It was observed that the two samples tended to react and stop reacting at essentially the same time. An estimated dissolution rate for the initial sample was calculated at $0.108 \mathrm{mg} / \mathrm{min}-\mathrm{cm}^{2}$ across the 5.5-hour test. Considering the differences between the mixing test and the rate measurement tests, the rate shows good agreement with the value of Table 2.

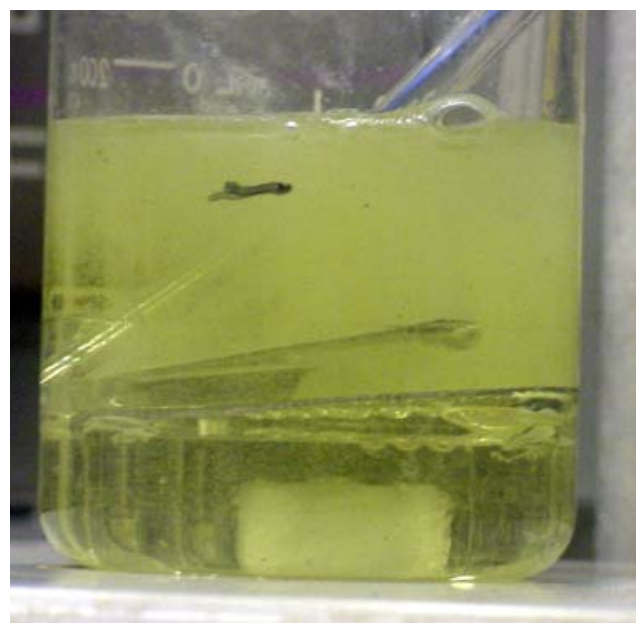

Figure 5. Dissolution in $4 \mathrm{M} \mathrm{HNO}_{3}$ $0.025 \mathrm{M} \mathrm{KF} / 2 \mathrm{~g} / \mathrm{L} \mathrm{B}$ at $100^{\circ} \mathrm{C}$

Pictures of the test are included as Attachment 1. The pictures at 5, 170, and 240 minutes clearly depict the abundance of fine gas bubbles being generated from the metal surface and filling both the dissolver insert and outer vessel. The pictures at 75 and 170 minutes show that a layer of dissolved uranium does not form as a stagnant layer near the metal surface. At most, the presence of blue U(IV) is slightly more concentrated at the bottom of the vessel than it is at the top.

When the mixing study was performed with $4 \mathrm{M}$ $\mathrm{HNO}_{3} / 0.025 \mathrm{M} \mathrm{KF}$ and $2 \mathrm{~g} / \mathrm{L}$ boron at room temperature, the behavior exhibits no resemblance to what is observed in the tests at $100^{\circ} \mathrm{C}$. After the sample comes in contact with the acid, only a few tiny bubbles are ever observed at one time. The size of the bubbles is comparable to the $2 \mathrm{M} \mathrm{HNO}_{3} /$ $0.025 \mathrm{M} \mathrm{KF}$ test, but the quantity is drastically reduced such that they are barely visible to the naked eye. As the test progresses, the gas generation remains barely visible.

As with the previous test, the presence of fluoride causes the uranium to form an initial blue U(IV) complex. Because of the scarcity of bubbles, the system is unmixed and the denser uranium solution sinks. The uranium solution leaves the dissolver

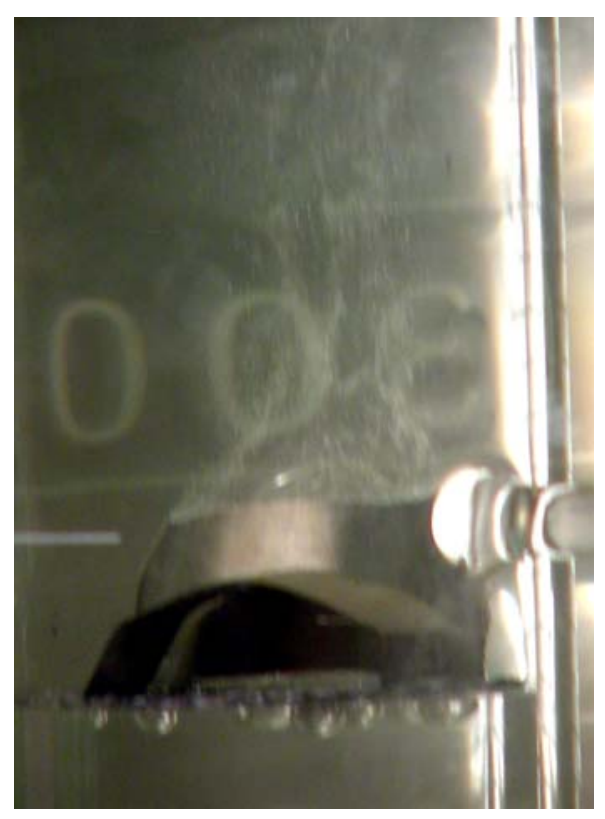

Figure 6. Dissolution in $3 \mathrm{M} \mathrm{HNO}_{3}$ $0.025 \mathrm{M} \mathrm{KF} / 2 \mathrm{~g} / \mathrm{L} \mathrm{B}$ at $25^{\circ} \mathrm{C}$ 
insert and is distributed fairly-evenly in the bottom section of the outer vessel. In spite of the absence of gas generation, an estimated dissolution rate for the sample was calculated at $0.135 \mathrm{mg} / \mathrm{min}-\mathrm{cm}^{2}$ across the 22-hour test. Considering the differences between the mixing test and the rate measurement tests, the value shows reasonable agreement with the value of Table 2 .

Pictures of the test are included as Attachment 2. All six pictures show the absence of mixing caused by gas generation. The last five pictures show the gradual increase in uranium concentration in the bottom of the test unit with the uranium level always remaining below the level of the uranium metal sample. At the same time, the pictures clearly indicate that no layer of dissolved uranium forms around the metal sample. The picture at 1165 minutes depicts the gradual conversion of blue U(IV) to a mixture of $\mathrm{U}(\mathrm{IV})$ and yellow uranyl $(\mathrm{U}(\mathrm{VI}))$ nitrate. The solution eventually changes completely to yellow $\mathrm{U}(\mathrm{VI})$.

The brief test using $3 \mathrm{M} \mathrm{HNO}_{3} / 0.025 \mathrm{M} \mathrm{KF}$ and $2 \mathrm{~g} / \mathrm{L}$ boron shows much resemblance to the behavior of the $2 \mathrm{M} \mathrm{HNO}_{3}$ test. Gas generation occurs as an effervescent stream of tiny bubbles that mix the contents of the vessel. The gas generation rate is muted because the solution was a mixture of solution used from the previous two mixing tests and probably has a reduced level of uncomplexed fluoride. A picture of the gas generation is shown as Figure 6. It should also be noted that the gas generation test at $1 \mathrm{M}$ $\mathrm{HNO}_{3} / 0.025 \mathrm{M} \mathrm{KF}$ and $2 \mathrm{~g} / \mathrm{L}$ boron was initiated at room temperature in order to observe the room temperature gas generation. Its gas generation characteristics at room temperature are consistent with both the $2 \mathrm{M}$ and $3 \mathrm{M}$ tests.

\section{DISCUSSION}

Much of the background for this discussion is drawn from an earlier document discussing the feasibility of dissolving this material in either H-Canyon or HB-Line. ${ }^{2}$

Chemistry Fundamentals: Several different acid-dependent chemical reactions can be written for the dissolution of uranium metal in $\mathrm{HNO}_{3}$. Plant experience indicates that the dissolution reaction is best represented by: ${ }^{3}$

$$
\mathrm{U}+4 \mathrm{HNO}_{3} \rightarrow \mathrm{UO}_{2}\left(\mathrm{NO}_{3}\right)_{2}+2 \mathrm{NO}+2 \mathrm{H}_{2} \mathrm{O}
$$

It has been proposed that the dissolution of aluminum in $\mathrm{HNO}_{3}$ might provide insight into the dissolution chemistry of uranium. ${ }^{4}$

$$
\begin{array}{l|l}
\left.\mathrm{HNO}_{3}\right] & \mathrm{Al}+6 \mathrm{HNO}_{3} \rightarrow \mathrm{Al}\left(\mathrm{NO}_{3}\right)_{3}+3 \mathrm{NO}_{2}+3 \mathrm{H}_{2} \mathrm{O} \\
\text { Increase } & \mathrm{Al}+4 \mathrm{HNO}_{3} \rightarrow \mathrm{Al}\left(\mathrm{NO}_{3}\right)_{3}+\mathrm{NO}+2 \mathrm{H}_{2} \mathrm{O} \\
& 8 \mathrm{Al}+30 \mathrm{HNO}_{3} \rightarrow 8 \mathrm{Al}\left(\mathrm{NO}_{3}\right)_{3}+3 \mathrm{~N}_{2} \mathrm{O}+15 \mathrm{H}_{2} \mathrm{O} \\
& 10 \mathrm{Al}+36 \mathrm{HNO}_{3} \rightarrow 10 \mathrm{Al}\left(\mathrm{NO}_{3}\right)_{3}+3 \mathrm{~N}_{2}+18 \mathrm{H}_{2} \mathrm{O} \\
& 2 \mathrm{Al}+6 \mathrm{HNO}_{3} \rightarrow 2 \mathrm{Al}\left(\mathrm{NO}_{3}\right)_{3}+3 \mathrm{H}_{2}
\end{array}
$$


All of the reactions occur simultaneously during aluminum metal dissolution. However, at higher $\mathrm{HNO}_{3}$ concentrations, the dissolution shifts towards Eq. (2). At lower acid concentrations, the dissolution shifts towards Eq. (6). Experience suggests that Eq. (3) is the dominant reaction in 6-8M nitric acid, which is analogous to Eq. (1).

Offgas Composition and Hydrogen Generation: It is known that the reaction of uranium metal with $\mathrm{HNO}_{3}$ has the potential to form hydrogen gas. It is also known that the presence of high concentrations of $\mathrm{HNO}_{3}$ during the reaction sets up competing reactions that inhibit the formation of hydrogen gas. Lower hydrogen generation rates as a function of higher $\mathrm{HNO}_{3}$ concentrations has been observed for uranium metal dissolution and other analogous systems, which is in agreement with the dissolution of aluminum as a function of $\mathrm{HNO}_{3}$ concentration.

The literature shows that in $55 \% \mathrm{HNO}_{3}(11.6 \mathrm{M})$ the percent hydrogen generated in the offgas is $0.01 \%$ by volume. ${ }^{5}$ Similar behavior was observed in the cathode compartment of equipment employing electrochemical dissolution techniques. In $2 \mathrm{M} \mathrm{HNO}_{3}$, nominal hydrogen generation was $2-3 \%$ by volume. In $4 \mathrm{M} \mathrm{HNO}_{3}$, the hydrogen rate drops to nominally $0.4 \%$. In $6 \mathrm{M} \mathrm{HNO}_{3}$ and higher, the hydrogen generation rate drops to less than $0.1 \%$ by volume. ${ }^{6}$ As a result, literature data show that hydrogen evolution is very low at concentrations above $1 \mathrm{M}$ or $2 \mathrm{M} \mathrm{HNO}_{3} .{ }^{4}$ Conversely, below $2 \mathrm{M} \mathrm{HNO}_{3}$, hydrogen generation rates may exceed the lower flammability limit (LFL) of $4 \%{ }^{6}$ The best explanation of this behavior is given with respect to the chemical reaction for aluminum dissolution in $\mathrm{HNO}_{3}$ listed above. At lower acid concentrations, the dissolution shifts towards Eq.(6) where hydrogen generation occurs.

The data in Table 4 show reasonable agreement with the parallel chemistry of aluminum and earlier data with uranium. As acid concentration decreases, dissolution of uranium shifts towards Eq. (6), and $\mathrm{H}_{2}$ and nitrogen oxide (NO) concentrations increase. Hydrogen and $\mathrm{NO}$ are products of a more reductive environment when compared to $\mathrm{NO}_{2}$ (Eq. 2). The only exception to the trend is at $7 \mathrm{M} \mathrm{HNO}_{3}$. Because of the presence of oxygen in the sample, it is likely that air in the sample reacted with NO since NO reacts with air to form $\mathrm{NO}_{2}{ }^{5}$

Conversely, as acid concentration increases, dissolution shifts towards Eq. (2), and $\mathrm{NO}_{2}$ concentration increases since $\mathrm{NO}_{2}$ is the product of a more oxidative system. The only exception is at $1 \mathrm{M} \mathrm{HNO}_{3}$. The difference is probably due to the definition of unknowns in Table 3 as purely $\mathrm{NO}_{2}$. As Eq. (4) shows, a decrease in acid might also produce an increase in $\mathrm{N}_{2} \mathrm{O}$. However, $\mathrm{N}_{2} \mathrm{O}$ is unidentifiable by the gas chromatography method used and would be grouped with $\mathrm{NO}_{2}$. One flaw in the gas data of Table 4 relative to Eqs. (2)-(6) is the absence of nitrogen in any of the lower acidity samples. Yet this statement is predicated on the assumption that uranium dissolution chemistry will perfectly mirror that of aluminum. That may be a faulty assumption. Other possibilities are that the acid concentration range for Eq. (5) is very narrow and does not apply to the conditions tested, or not enough $\mathrm{N}_{2}$ generation occurs to measure $\mathrm{N}_{2}$ reliably. 
It is interesting to note the significant difference between the gas composition in $4 \mathrm{M}$ $\mathrm{HNO}_{3}$ compared to $4 \mathrm{M} \mathrm{HNO}_{3} / 0.025 \mathrm{M} \mathrm{KF}$ and $2 \mathrm{~g} / \mathrm{L}$ boron. Based on the presence of $\mathrm{U}(\mathrm{IV})$ in the mixing tests (blue color observed in Attachments 1 and 2) instead of the typical yellow U(IV) (see Figure 5), there seems to be a shift from more oxidative conditions $\left(4 \mathrm{M} \mathrm{HNO}_{3}\right)$ to more reductive ones $\left(4 \mathrm{M} \mathrm{HNO}_{3} / 0.025 \mathrm{KF}\right.$ and $2 \mathrm{~g} / \mathrm{L}$ boron). It is possible that the shift is caused by participation of $\mathrm{KF}$ in the reaction. The more reductive environment translates into reduced $\mathrm{NO}_{2}$ formation.

What is most important from an operations perspective is the fact that hydrogen generation in $2 \mathrm{M} \mathrm{HNO}_{3}$ and higher $\mathrm{HNO}_{3}$ concentrations is well below the LFL of $4 \%$ for hydrogen. Consequently, as long as acid concentrations are maintained above $1.5 \mathrm{M}$ $\mathrm{HNO}_{3}$, the LFL for $\mathrm{H}_{2}$ will not be exceeded even in the absence of a purge gas stream. Even in $1.0 \mathrm{M} \mathrm{HNO}_{3} / 0.025 \mathrm{M} \mathrm{KF}$ and $2 \mathrm{~g} / \mathrm{L}$ boron, the hydrogen concentration is only marginally above the LFL such that the operation of the vessel sparge systems will sufficiently dilute the reaction gases to below 4 volume percent.

Calculations indicate that if $25 \mathrm{~kg}$ of scrap is dissolved in a 7500-liter batch in H-Canyon, reactions will reduce the acid concentration by about $0.05 \mathrm{M} \mathrm{HNO}_{3}$. If carbon steel (to be used in the dissolver insert) dissolves in manner analogous to Eq. (3), calculations show that $47 \mathrm{~kg}$ of carbon steel could be dissolved before the $\mathrm{HNO}_{3}$ concentration in the dissolver is reduced to $1.5 \mathrm{M}$.

Gas Generation Rates: The reaction of uranium metal in nitric acid was expected to be similar to that of the $\mathrm{Pu}-\mathrm{Al}$ scrub alloy that was dissolved in $4 \mathrm{M} \mathrm{HNO}_{3} / 0.15 \mathrm{M}$ calcium fluoride. The Pu-Al scrub alloy "solids dissolve readily with light, effervescent gas generation at the material surface." "This presumption turned out to be a reasonable assessment of reaction as can be readily seen from the pictures in Attachment 1.

The amount of gas generation was initially estimated using Equation 1 that assumes two moles of $\mathrm{NO}$ will be generated per mole of uranium. On a gram-of-uranium basis, assuming no absorption into the solution, the estimated gas generation ratio is $188 \mathrm{~mL} / \mathrm{g}$ uranium. Table 4 shows an approximate gas generation rate of $107 \mathrm{~mL} / \mathrm{g}$ uranium for dissolution in $4-7 \mathrm{M} \mathrm{HNO}_{3}$ and $132 \mathrm{~mL} / \mathrm{g}$ uranium in $1 \mathrm{M}$ and $4 \mathrm{M} \mathrm{HNO}_{3} / 0.025 \mathrm{M} \mathrm{KF}$ and $2 \mathrm{~g} / \mathrm{L}$ boron. It is likely that the data for $2 \mathrm{M} \mathrm{HNO}_{3} / 0.025 \mathrm{M} \mathrm{KF}$ and $2 \mathrm{~g} / \mathrm{L}$ boron of 64 $\mathrm{mL} / \mathrm{g}$ uranium represents a problem in the gas collection setup for that experiment.

Based on the observed gas generation quantities, it appears that some of the gases are being absorbed before they can be released from the test vessel. In only $\mathrm{HNO}_{3}$, the percent $\mathrm{NO}_{2}$ is above $50 \%$, and below $15 \%$ for those tests with $\mathrm{HNO}_{3} / 0.025 \mathrm{M} \mathrm{KF}$ and 2 $\mathrm{g} / \mathrm{L}$ boron. It is known that $\mathrm{NO}_{2}$ can dissolve into water and other aqueous systems. ${ }^{4,5}$ The occurrence of higher $\mathrm{NO}_{2}$ absorption in $\mathrm{HNO}_{3}$ in the absence of $\mathrm{KF}$ (hence, overall gas generation being lower) can be seen in Table 4 .

When a gas generation rate of $130 \mathrm{~mL} / \mathrm{g}$ uranium is multiplied by the expected dissolution rate for $2 \mathrm{M} \mathrm{HNO}_{3} / 0.025 \mathrm{M} \mathrm{KF}$ and $2 \mathrm{~g} / \mathrm{L}$ boron of $2.35 \mathrm{mg}$ uranium $/ \mathrm{min}-\mathrm{cm}^{2}$, this yields an expected gas generation rate of $0.31 \mathrm{~mL} / \mathrm{min}-\mathrm{cm}^{2}$. This value is a small 
amount of gas even under the worst-case conditions being considered for the processing of the uranium scrap.

Reaction Rates in Nitric Acid: Earlier researchers measured the uranium dissolution rate at different concentrations of $\mathrm{HNO}_{3}$. At $\mathrm{HNO}_{3}$ concentrations above $2 \mathrm{M}$, the instantaneous reaction rate at boiling was stated as:

$$
\mathrm{R}=\left(0.0115 \mathrm{mg} / \mathrm{min}-\mathrm{cm}^{2}-\mathrm{M}^{3}\right)^{*}\left[\mathrm{NO}_{3}^{-}\right]^{3}
$$

$\mathrm{R}$ is in $\mathrm{mg} / \mathrm{min}-\mathrm{cm}^{2}$ and $\left[\mathrm{NO}_{3}{ }^{-}\right]$is the total nitrate concentration in moles per liter. ${ }^{3}$ Above $2 \mathrm{M} \mathrm{HNO}_{3}$ at boiling, the literature shows the instantaneous dissolution rate to be independent of either the acid or the uranium concentration. ${ }^{3,5}$ The reaction rates observed for these experiments are well below what the rates are estimated by Eq. (7). A comparison of measured and calculated values is contained in Table 5.

Table 5. Experimental and Calculated Dissolution Rates

\begin{tabular}{|l|c|c|c|}
\hline Solution & $\begin{array}{c}\text { Expt. Rate } \\
\left(\mathbf{m g} / \mathbf{m i n}-\mathbf{c m}^{2}\right)\end{array}$ & $\begin{array}{c}\text { Calc. Rate } \\
(\mathbf{m g} / \text { min-cm }\end{array}$ & $\begin{array}{c}\text { Percent } \\
\text { Difference }\end{array}$ \\
\hline 2M HNO $_{3}$ & 0.051 & 0.092 & 44.6 \\
2M HNO $_{3} / \mathbf{2 M ~ N a N O}_{3}$ & 0.254 & 0.736 & 65.5 \\
4M HNO $_{3}$ & 0.309 & 0.736 & 58.0 \\
4M HNO $_{3} / \mathbf{M M ~ N a N O}_{3}$ & 1.258 & 3.944 & 68.1 \\
7M HNO $_{3}$ & 1.285 & 3.944 & 67.4 \\
10M HNO $_{3}$ & 4.057 & 11.500 & 64.7 \\
\hline
\end{tabular}

Although rates seem to be a function of total nitrate concentration above $2 \mathrm{M} \mathrm{HNO}_{3}$, the difference between all measured and calculated values is very large, typically in the 58$68 \%$ difference range. There is not enough detail in the literature to understand why the data are different, but two reasons can be speculated. The first is that in the handling of SRTC samples prior to being added to the test vessel, a thin oxide coating is able to build up on the surface of the metal which can impede the reaction at the start of the tests, and perhaps throughout the tests. It is also possible that since the sample is oriented primarily in the horizontal position (see Figure 5), the presence of gases along the bottom surface of the samples restricts solution access to the metal surface.

Effect of Fluoride and Boron: The effects of boron and fluoride on uranium metal dissolution rate were not well documented in the available literature. The only relevant understanding is analogous work performed with plutonium. To obtain acceptable dissolution rates of plutonium metal in low concentrations of $\mathrm{HNO}_{3}$ (for $\mathrm{H}$-Canyon or HB-Line), the use of fluoride is required to dissolve the oxide coating that tends to form on the metal surface. Without fluoride, the oxide coating remains at the metal surface and impedes dissolution. ${ }^{7}$ Boron is frequently added to Savannah River Site canyon dissolvers as a component of dissolution at $2 \mathrm{~g} / \mathrm{L}$ to function as a neutron poison. It has the added effect of complexing some of the available fluoride. ${ }^{8}$ 
Comparable behavior was observed with uranium metal. The data from Table 2 are plotted in Figure 7 to show the effect of fluoride. The data show that dissolution rate is limited by the presence of the oxide coating for KF concentrations between 0 and $0.05 \mathrm{M}$ KF. The effect of $\mathrm{HNO}_{3}$ concentration appears negligible until there is sufficient KF $(0.1 \mathrm{M})$ to remove the oxide coating, especially when considering that the dissolution temperature for the $2 \mathrm{M} \mathrm{HNO}_{3}$ tests is only $5^{\circ} \mathrm{C}$ lower than the $4 \mathrm{M} \mathrm{HNO}_{3}$ tests.

The addition of KF to the system accelerates the dissolution rates by removing the oxide barrier to $\mathrm{HNO}_{3}$ dissolution. In effect, the data indicates that an oxide coating inhibits $\mathrm{HNO}_{3}$ dissolution at lower KF concentrations. The data also suggest that the oxide coating persists or continually reforms at the material surface in the presence of $0-0.05 \mathrm{M}$ $\mathrm{KF}$ and $2 \mathrm{~g} / \mathrm{L}$ boron. It is only at higher $\mathrm{KF}$ concentrations $(>0.1 \mathrm{M})$ that the oxide coating has been sufficiently removed to see an effect from $\mathrm{HNO}_{3}$ concentration.

This behavior is consistent with both the comparative dissolution rates and empirical data showing the metal surfaces to be dull when withdrawn from solutions at lower KF concentrations and shiny when KF concentrations are higher (see Figure 4). Only samples dissolved in 0.1M KF had a level of shine that suggests the absence oxide. When a sample was not pickled to remove the oxide coating prior to rate testing, the dissolution rate increased in comparison to the rate of a pickled sample (0.323 vs. 0.137 $\mathrm{mg} / \mathrm{min}-\mathrm{cm}^{2}$ ) because of rapid oxide dissolution. The change in rate should not be confused with an increase rate in metal dissolution, rather the quick dissolution of oxide from the sample surface, which is on the order of five weight percent. In addition, the sample surface color changed from charcoal gray to dull silver. This indicates that pickling is not required prior to dissolving samples in $2 \mathrm{M} \mathrm{HNO}_{3} / 0.025 \mathrm{M} \mathrm{KF}$ and $2 \mathrm{~g} / \mathrm{L}$ boron.

Figure 7. Effect of KF/Boron on Dissolution Rates

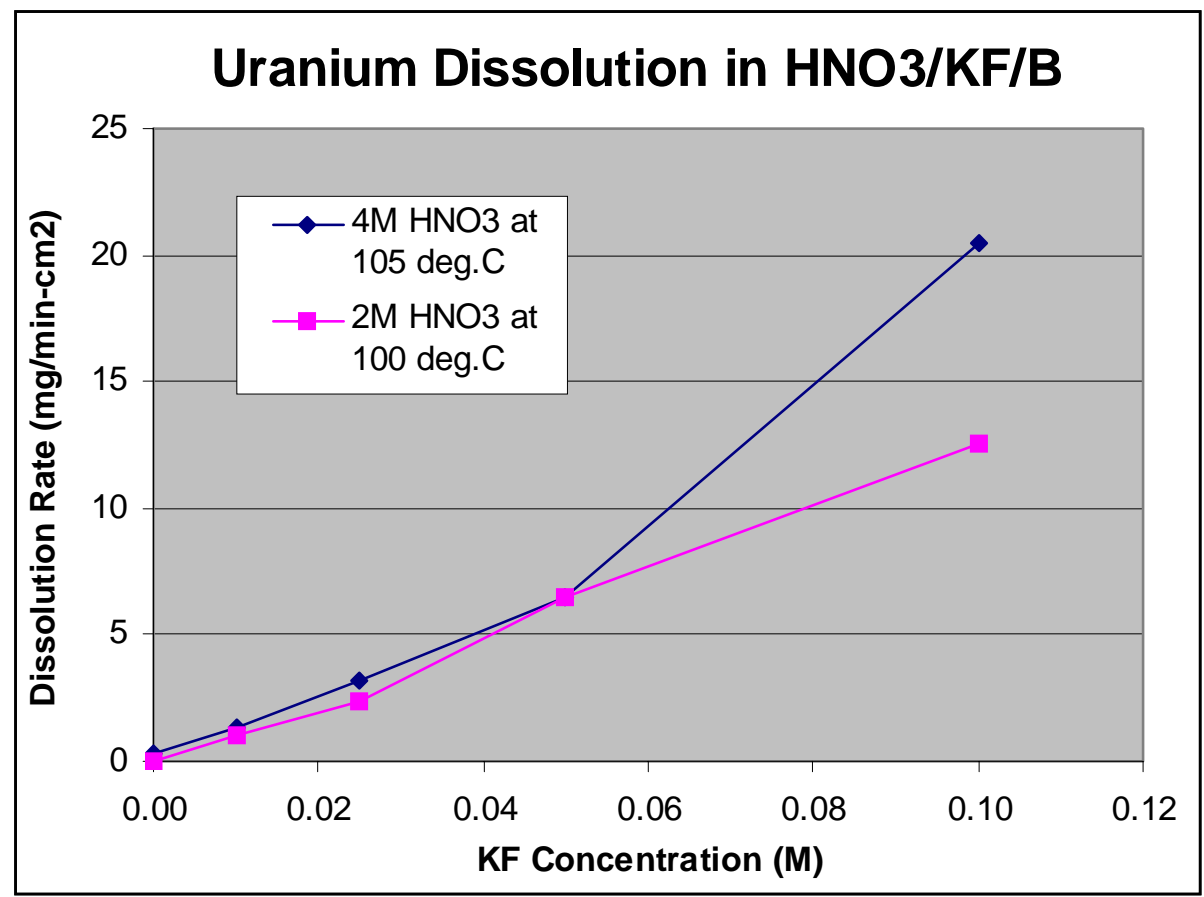


Effect of Temperature: The literature shows that increases in temperature produce increases in dissolution rate. This behavior is as expected. Treatment of the data in the literature indicates that the effect on reaction rate is essentially linear within the temperature range of interest. ${ }^{3}$ This behavior seems questionable since an exponential type relationship is typically expected.

Two plots of the data are shown in Attachment 3 for the tests containing only $\mathrm{HNO}_{3}$ and those with $\mathrm{HNO}_{3} / \mathrm{KF}$ and boron. Since the rate data are plotted in a semi-log manner, linearity of the data will indicate whether or not there is an exponential type relationship with respect to temperature. The data plots indicate a high degree of linearity and, as a result, an exponential relationship with respect to temperature consistent with what should be expected.

Of the seven data sets, the trendlines for six of the data sets yield an $\mathrm{R}^{2}$ value of 0.97 or greater, thereby indicating a high degree of linearity. Only one data set, $10 \mathrm{M} \mathrm{HNO}_{3}\left(\mathrm{R}^{2}\right.$ $=0.87$ ), exhibits less linearity. The data of Reference 3 at $10.4 \mathrm{M} \mathrm{HNO}_{3}$ possesses a linearity of 0.93 but has a slope comparable to that of the $10 \mathrm{M} \mathrm{HNO}_{3}$ data. The decrease in linearity in $10 \mathrm{M}$ and $10.4 \mathrm{M} \mathrm{HNO}_{3}$ may be caused by a high gas generation rate at $105^{\circ} \mathrm{C}$, which interferes with the ability of solution to access the surface of the metal.

The data also agree with what was observed in Figure 7. In 0-0.025M KF, the reaction rate as a function of temperature is independent of whether the $\mathrm{HNO}_{3}$ concentration is $2 \mathrm{M}$ or $4 \mathrm{M}$. The lines for $2 \mathrm{M}$ or $4 \mathrm{M} \mathrm{HNO}_{3}$ in $0.01 \mathrm{M} \mathrm{KF}$ and $2 \mathrm{~g} / \mathrm{L}$ boron are essentially identical; the behavior in $0.025 \mathrm{M} \mathrm{KF}$ and $2 \mathrm{~g} / \mathrm{L}$ boron shows little difference between $2 \mathrm{M}$ and $4 \mathrm{M} \mathrm{HNO}_{3}$.

\section{Proposed Chemical Reactions:}

The above data in conjunction with the literature $e^{3,4,5}$ make it possible to propose a series of chemical reactions at $100-105^{\circ} \mathrm{C}$ to describe uranium metal dissolution under varying acid conditions. The reactions are proposed (not explicitly in the literature except Eqs. $(10)^{9}$ and $\left.(11)^{3}\right)$ to facilitate a better understand of the system chemistry as a function of acid concentration. The reactions parallel those of Eqs.(2)-(6).

\begin{tabular}{l|c|c|c|c|} 
& $\mathrm{U}+6 \mathrm{HNO}_{3} \rightarrow \mathrm{UO}_{2}\left(\mathrm{NO}_{3}\right)_{2}+3 \mathrm{NO}_{2}+\mathrm{NO}+2 \mathrm{H}_{2} \mathrm{O}$ \\
& $2 \mathrm{U}+10 \mathrm{HNO}_{3} \rightarrow 2 \mathrm{UO}_{2}\left(\mathrm{NO}_{3}\right)_{2}+3 \mathrm{NO}_{2}+3 \mathrm{NO}+5 \mathrm{H}_{2} \mathrm{O}$ \\
Increase & $\mathrm{U}+4.5 \mathrm{HNO}_{3} \rightarrow \mathrm{UO}_{2}\left(\mathrm{NO}_{3}\right)_{2}+1.57 \mathrm{NO}+0.84 \mathrm{NO}_{2}+$ \\
& $0.005 \mathrm{~N}_{2} \mathrm{O}+0.043 \mathrm{~N}_{2}+2.25 \mathrm{H}_{2} \mathrm{O}$ \\
& $\mathrm{U}+4 \mathrm{HNO}_{3} \rightarrow \mathrm{UO}_{2}\left(\mathrm{NO}_{3}\right)_{2}+2 \mathrm{NO}+2 \mathrm{H}_{2} \mathrm{O}$ \\
& $5 \mathrm{U}+14 \mathrm{HNO}_{3} \rightarrow 5 \mathrm{UO}_{2}\left(\mathrm{NO}_{3}\right)_{2}+2 \mathrm{~N}_{2} \mathrm{O}+7 \mathrm{H}_{2}$
\end{tabular}


System Mixing:

The mixing study data reveal the type of mixing behavior that can be expected at room temperature or $100^{\circ} \mathrm{C}$ for either $2 \mathrm{M}$ or $4 \mathrm{M} \mathrm{HNO}_{3}$ with $0.025 \mathrm{M} \mathrm{KF}$ and $2 \mathrm{~g} / \mathrm{L}$ boron. At $2 \mathrm{M} \mathrm{HNO}_{3}$, dissolution at room temperature generated a visible gas stream of extremely fine bubbles. The gas stream was able to mix the liquid in the dissolver insert and prevent the formation of a uranium layer around the metal (Attachment 1). The gas generation rate for $2 \mathrm{M} \mathrm{HNO}_{3}$ at room temperature is only a fraction ( $4-6 \%$ based on Table 2) of what it will be at $100^{\circ} \mathrm{C}$ for either $2 \mathrm{M}$ or $4 \mathrm{M} \mathrm{HNO}_{3}$ with $\mathrm{KF}$ and boron. Therefore, thorough mixing will also be present in the dissolver insert at $100^{\circ} \mathrm{C}$ in either $2 \mathrm{M}$ or $4 \mathrm{M} \mathrm{HNO}_{3}$.

In $4 \mathrm{M} \mathrm{HNO}_{3} / 0.025 \mathrm{M} \mathrm{KF}$ and $2 \mathrm{~g} / \mathrm{L}$ boron at room temperature, very little gas generation is observed at first and almost none is visible after about six hours. Nonetheless, uranium dissolves at a rate comparable to $2 \mathrm{M} \mathrm{HNO} / 0.025 \mathrm{M} \mathrm{KF}$ and $2 \mathrm{~g} / \mathrm{L}$ boron. As the uranium dissolved, the more-dense liquid settled to the bottom of the vessel away from the sample (Attachment 2). The uranium (blue due to U(IV)) spreads evenly throughout the solution below the sample even though no mixing was present. Although this shows that the use of $4 \mathrm{M} \mathrm{HNO}_{3}$ in boron and $\mathrm{KF}$ does not present a criticality hazard at room temperature, it produces a less desirable condition than that of $2 \mathrm{M} \mathrm{HNO}_{3}$.

Use of an intermediate-acid case $\left(3 \mathrm{M} \mathrm{HNO}_{3}\right)$ and a lower-acid case $\left(1 \mathrm{M} \mathrm{HNO}_{3}\right)$ both showed reaction characteristics comparable to the $2 \mathrm{M} \mathrm{HNO}_{3}$ test. A steady stream of small gas bubbles provides adequate mixing in the dissolver insert at room temperature. Based on the reaction characteristics in conjunction with gas generation studies, $2 \mathrm{M}$ $\mathrm{HNO}_{3}$ with $0.025 \mathrm{M} \mathrm{KF}$ and $2 \mathrm{~g} / \mathrm{L}$ boron will be recommended as the preferred solution for $\mathrm{H}$-Canyon processing.

\section{CONCLUSIONS/RECOMMENDATIONS}

Uranium metal dissolution experiments have shown that acceptable dissolution rates can achieved for the Pu-contaminated scrap program using either high $\mathrm{HNO}_{3}$ concentrations $(>7 \mathrm{M})$ or low $\mathrm{HNO}_{3}$ concentrations $(1-4 \mathrm{M})$ in the presence of fluoride $(0.025 \mathrm{M})$ and boron $(2 \mathrm{~g} / \mathrm{L})$. During dissolution in the presence of little or no fluoride, an oxide coating forms on the surface of the uranium metal and impedes the reaction rate. At low acid concentrations in the absence of fluoride, the reaction rates are unacceptably slow for the $\mathrm{Pu}$-contaminated scrap program. Tests have shown that samples with thick oxide coatings dissolve readily in $2 \mathrm{M} \mathrm{HNO}_{3} / 0.025 \mathrm{M} \mathrm{KF}$ and $2 \mathrm{~g} / \mathrm{L}$ boron. The observed behavior of dissolution rates as a function of acid concentration and temperature are in general agreement with what is expected based on the literature.

Gas generation tests have demonstrated that hydrogen generation is not an issue at the conditions being proposed for plant operations. At $\mathrm{HNO}_{3}$ concentrations above $2 \mathrm{M}$, the hydrogen component of the offgas is less that $0.1 \%$ by volume. When the $\mathrm{HNO}_{3}$ is reduced to $1 \mathrm{M}$ in the presence of $\mathrm{KF}$ and boron, the hydrogen concentration (corrected) 
rises above the LFL to $5.4 \%$ by volume. Sparging and the operation of the dissolver offgas system will dilute this concentration below the LFL.

Mixing studies have shown that criticality is not a likely event in the dissolver insert either at room temperature or at $100^{\circ} \mathrm{C}$. In $2 \mathrm{M} \mathrm{HNO}_{3} / 0.025 \mathrm{M} \mathrm{KF}$ and $2 \mathrm{~g} / \mathrm{L}$ boron at room temperature, a steady gas stream is generated from the surface of uranium metal. The gas generation rate is sufficient to mix the contents of the dissolver insert. In $4 \mathrm{M}$ $\mathrm{HNO}_{3} / 0.025 \mathrm{M} \mathrm{KF}$ and $2 \mathrm{~g} / \mathrm{L}$ boron, minimal gas generation and mixing occurs. Instead of mixing the uranium, the more-dense uranium solution drops down out of the dissolver insert and away from the metal being dissolved. Variations in acid concentration away from $2 \mathrm{M} \mathrm{HNO}_{3}$ should not be a problem since dissolution in both $1 \mathrm{M}$ or $3 \mathrm{M} \mathrm{HNO}_{3}$ (with $\mathrm{KF}$ and boron) at room temperature produces gas generation comparable to that of $2 \mathrm{M}$ $\mathrm{HNO}_{3}$. When the temperature is raised to $100^{\circ} \mathrm{C}$, the gas generation at $1-4 \mathrm{M} \mathrm{HNO}_{3}$ exceeds that of $2 \mathrm{M} \mathrm{HNO}_{3}$ at room temperature and provides excellent mixing in the dissolver insert.

Based on reactions at room temperature and boiling, and the rates of reaction at $100^{\circ} \mathrm{C}$, SRTC recommends the use of $2 \mathrm{M} \mathrm{HNO}_{3} / 0.025 \mathrm{M} \mathrm{KF}$ and $2 \mathrm{~g} / \mathrm{L}$ boron at boiling in $\mathrm{H}-$ Canyon to process the Pu-contaminated scrap material.

\section{REFERENCES}

1. Katz, J.J, Seaborg, G.T. and Morss, L.R. The Chemistry of the Actinide Elements $\left(2^{\text {nd }}\right.$ Edition), Chapman and Hall (New York), 1986.

2. R. A. Pierce, "Feasibility of Dissolving Uranium Metal in HB-Line and H-Canyon," WSRC-TR-2003-00359, August 2003.

3. Colven, T.J, Cline, C.W. and Wible, A.E. "Processing of Irradiated Natural Uranium at Savannah River," DP-500. August 1960.

4. Long, J.T. Engineering for Nuclear Fuel Reprocessing, American Nuclear Society, 1978.

5. Stoller, S.M. and Richards, R.B. Reactor Handbook, Fuel Reprocessing, Volume II $\left(2^{\text {nd }}\right.$ Edition), Interscience Publishers (New York), 1961.

6. Wheelwright, E.J., Bray, L.A. and Ryan, J.L. "Development of the CEPOD Process for Dissolving Plutonium Oxide and Leaching Plutonium from Scrap or Wastes," PNL-6483. March 1988.

7. Pierce, R.A. "Dissolution of Plutonuim Scrub Alloy and Anode Heel Materials in HCanyon," WSRC-TR-2003-00276. June 2003.

8. D. G. Karraker, et.al. "Flowsheet Modifications for Dissolution of Sand, Slag, and Crucible Residues in the F-Canyon Dissolvers," WSRC-TR-97-00395, December 1997.

9. D. L. Foster, J. E. Savolainen and R. G. Wymer. "Nuclear Reactor Fuel Dissolution." Proceedings of the International Conference on the Peaceful Uses of Atomic Energy, Volume 9, Reactor Technology and Chemical Processing, United Nations (New York, 1956), pp. 546-550. 
WSRC-TR-2003-00500, Rev. 0

Page 19 of 21

ATTACHMENT 1. $2 \mathrm{M} \mathrm{HNO}_{3} / 0.025 \mathrm{M} \mathrm{KF}$ and $2 \mathrm{~g} / \mathrm{L}$ Boron Mixing Study Pictures
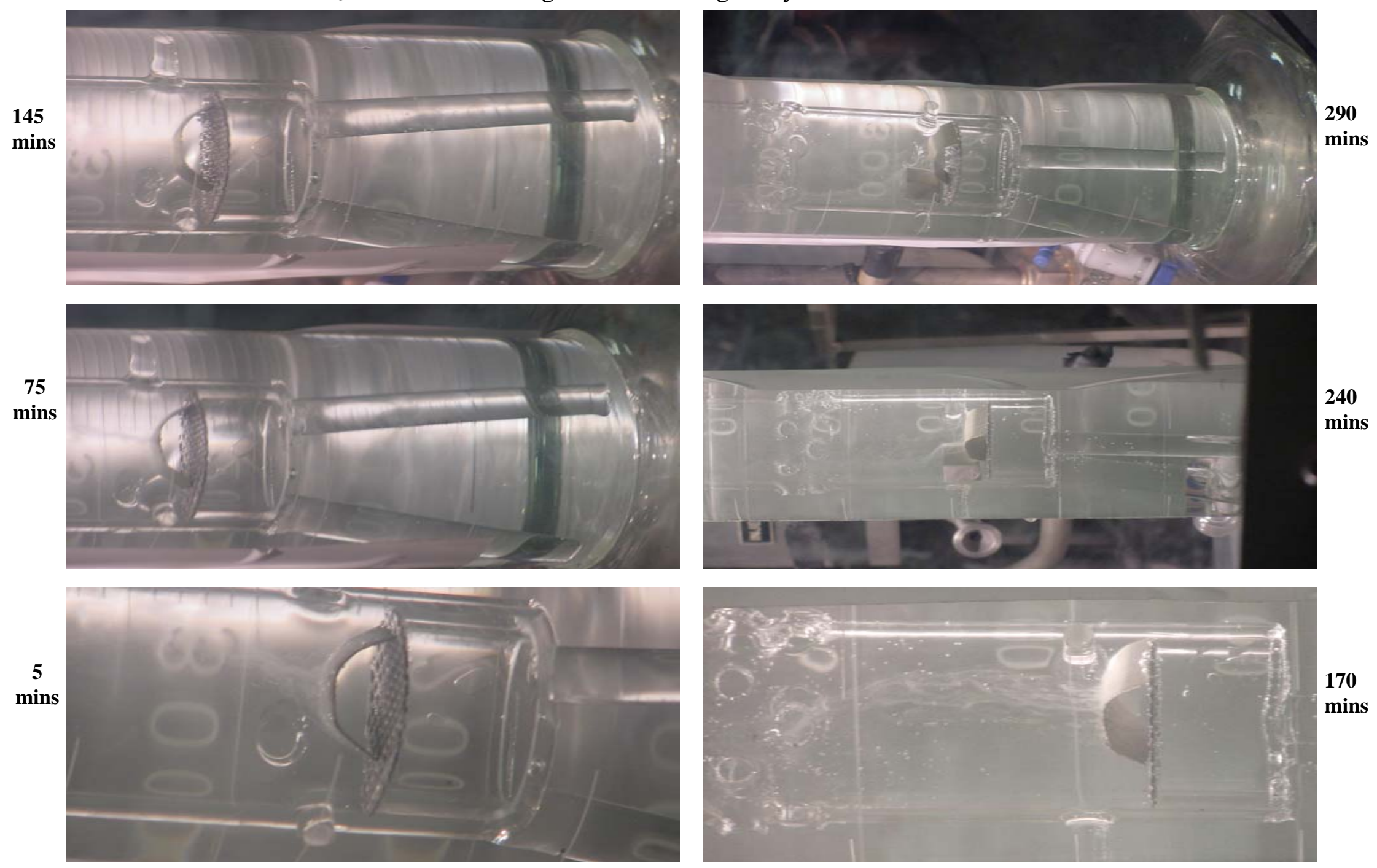
ATTACHMENT 2. $4 \mathrm{M} \mathrm{HNO}_{3} / 0.025 \mathrm{M} \mathrm{KF}$ and $2 \mathrm{~g} / \mathrm{L}$ Boron Mixing Study Pictures
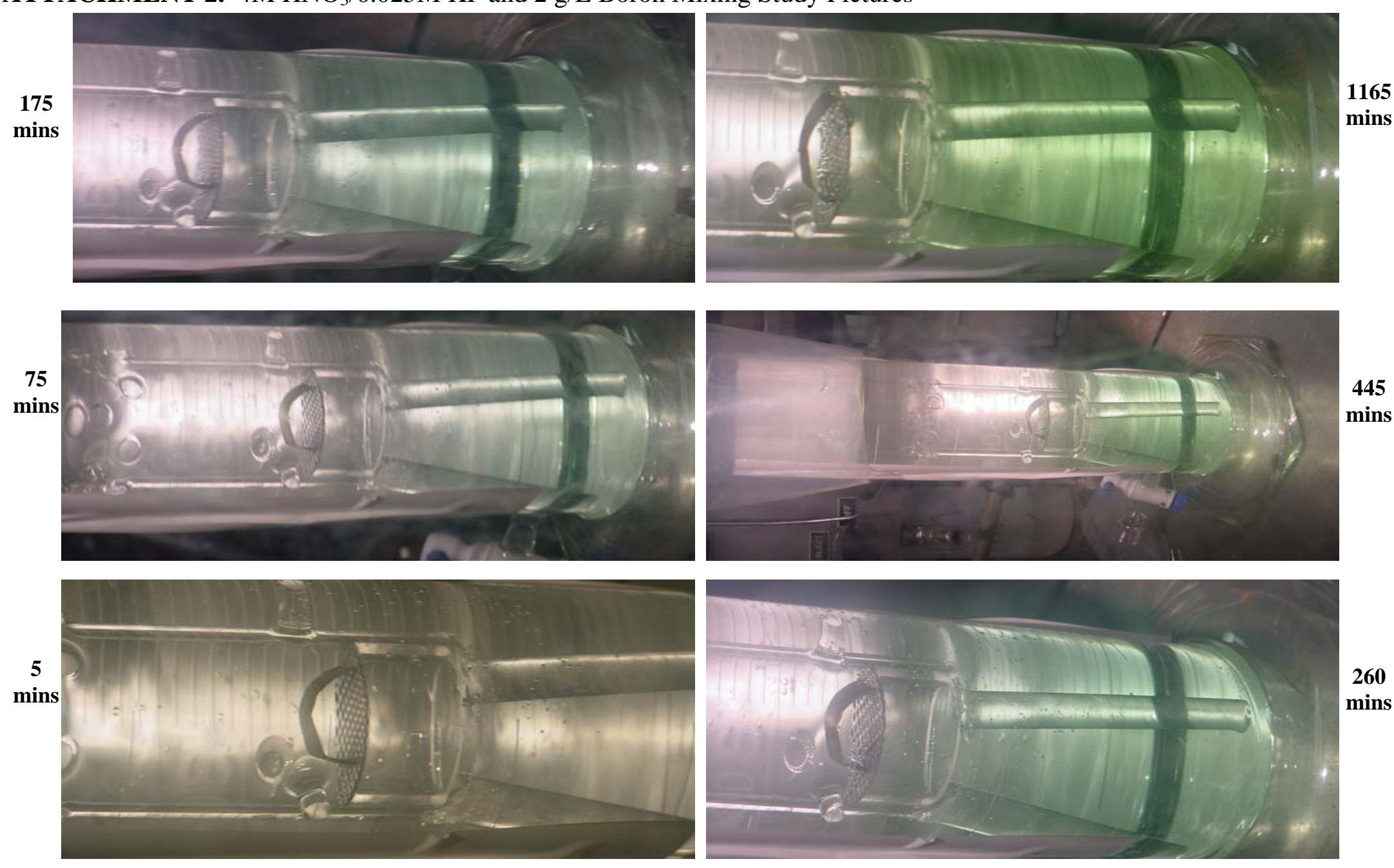
ATTACHMENT 3. Uranium Dissolution Rate Temperature Dependence
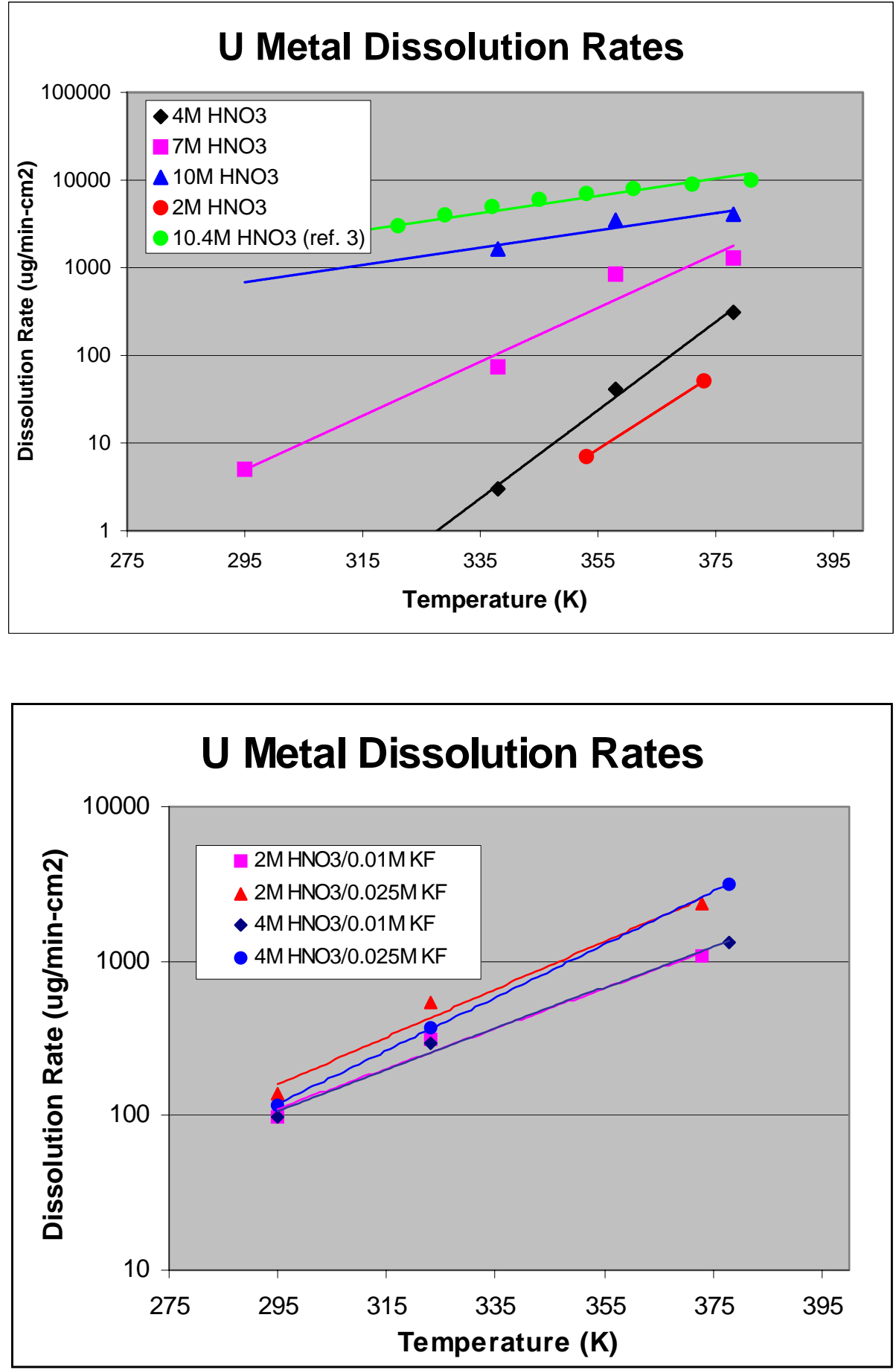